\title{
TOBACCO AND HEALTH
}

\section{THE CHANGING ROLE OF THE MEDIA}

ESTEVE FERNÁNDEZ

From the mid twentieth century, several studies showed that cigarette-smoking was related to the increase in the incidence of lung cancer. After their publication the tobacco industry felt threatened and used the media to counteract the effects these studies had on the population. From this perspective, the present article reviews the role of the media in the dissemination of tobacco-related information and the evolution in tobacco control policies that the approach has caused.

Keywords: tobacco, smoking, media, advertising, lobbying.

\section{WE KNOW THAT TOBACCO IS BAD}

Quite probably, almost every article or essay we read or write about tobacco today would start with a sentence like «Tobacco use kills nearly six million people annually, and it is estimated that it will cause a billion deaths during the 21st century» (Atusingwize, Lewis, \& Langley, 2015). We have known this for a few decades. At the beginning of 1960, two reports titled «Smoking and Health» confirmed the causal relationship between tobacco smoking and cancer and other diseases. The first, written by United Kingdom's Royal College of Physicians (1962), went largely unnoticed. The second was written by the North-American Luther L. Terry in 1964 (Surgeon General's Advisory Committee on Smoking and Health, 1964).

Evidence had accumulated during the preceding decades and in 1950, three important papers on the tobacco-related risks of disease or death were published, three case studies with cancer patients and control groups that gave the scientific evidence for the relationship between tobacco smoking and lung cancer. Two of the studies were conducted in the United States by independent groups. Levi, Goldstein and Gerhardt's study (1950) included 1,000 cancer patients and 600 cancer-free patients. All of them were asked in a questionnaire about their medical history, occupation and lifestyle, including smoking. The other study, published by Wynder and Graham (1950), included 684 lung cancer patients and 780 hospitalised cancer-free patients. Both studies consistently showed that the prevalence of tobacco use among the cases was much higher than among the members of the control group. The third study, conducted in the United Kingdom by Doll and Hill (1950), included 709 patients with lung cancer and another 709 patients without cancer. Information was collected using a questionnaire about tobacco use, age of starting the habit and degree of smoke inhalation. Doll and Hill observed that a higher frequency of smokers had lung cancer, and the fact that patients with the disease used more tobacco than the control group.

It is worth noting that the authors of the studies had great difficulty in publishing their research because, apart from using a new epidemiological design they used, they offered quite an uncomfortable answer to the question of the cause of the tragic lung cancer epidemic in the Western world. Smoking prevalence was very high, including the researchers themselves (Graham quit smoking in 1951 but died of lung cancer six years later). Even Graham warned Wynder when they were preparing the text: «You are going to have many difficulties. The smokers will not like your message. The tobacco interests will be vigorously opposed. The media and the government will be loath to support these 

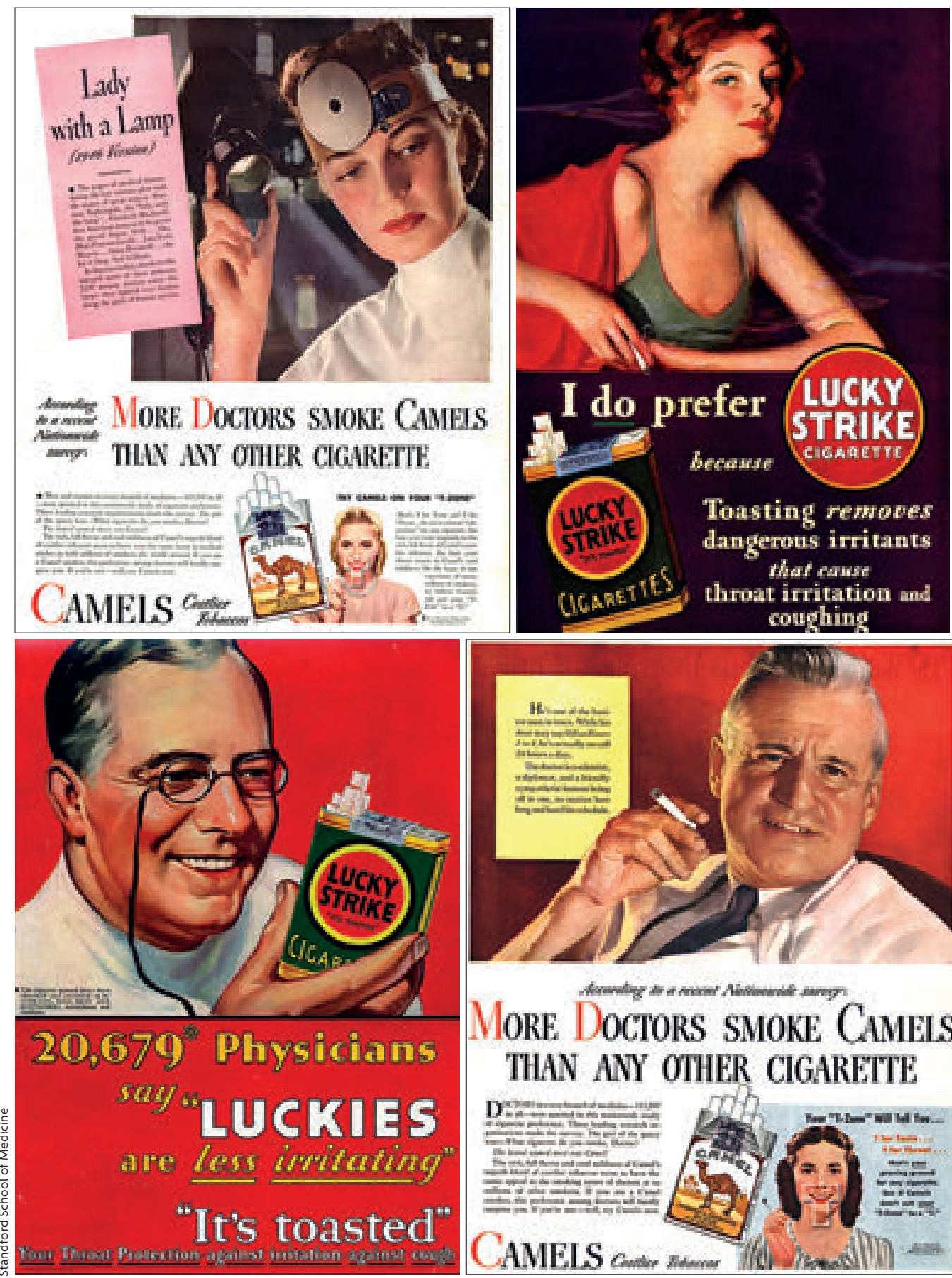

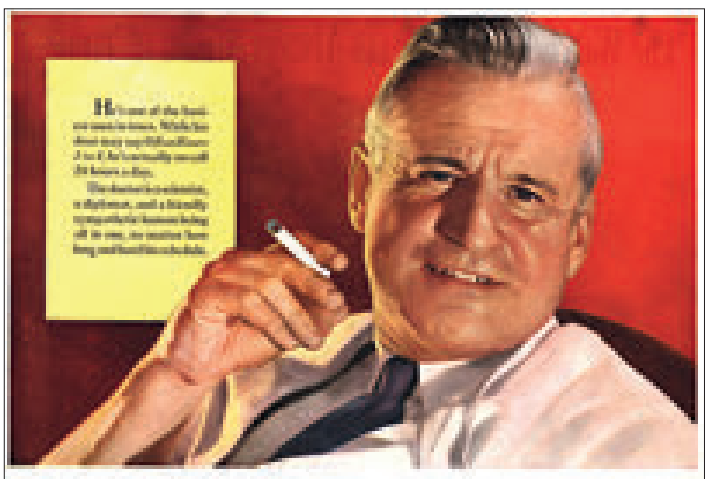

MORE DOCTORS SMOKE CAMEIS THAN ANY OTHER CIGARETTE

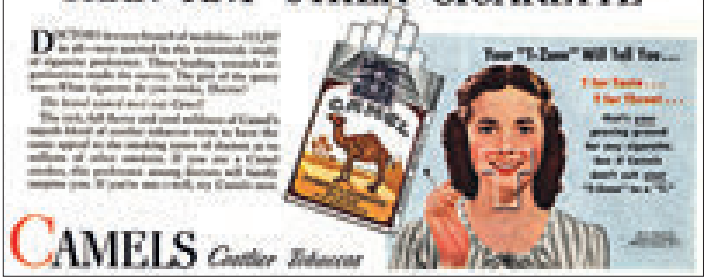

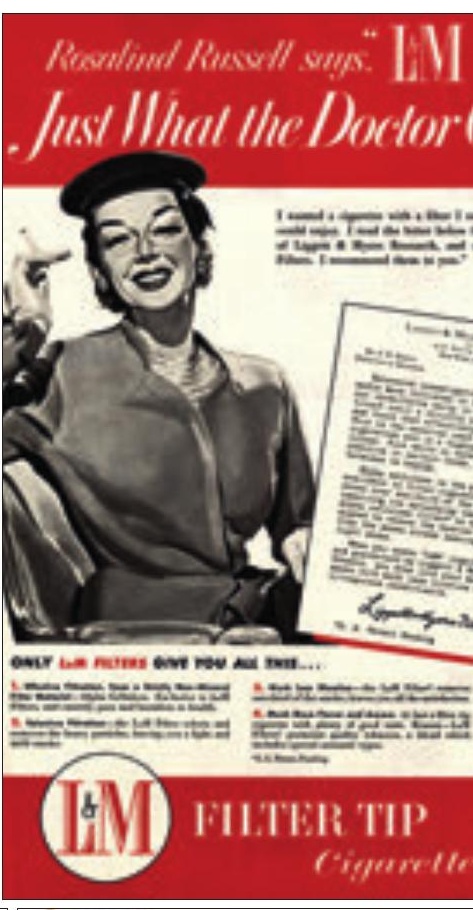

"Give vevu tunest a

Smolse a FIRESII e

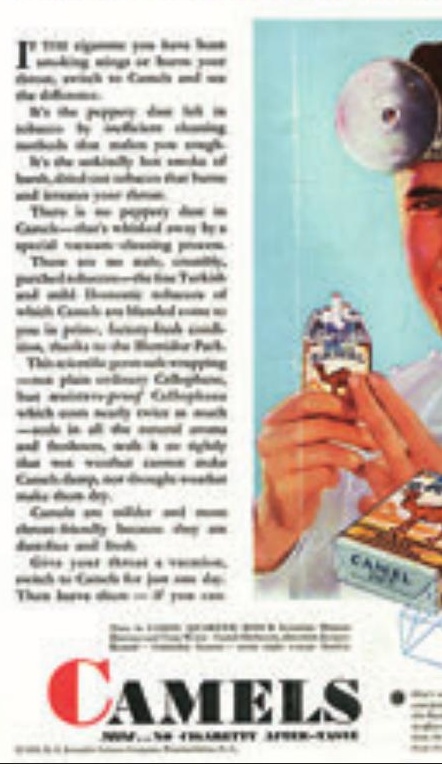

Figure 1. The tobacco industry used the image of healthcare professionals to publicise the merits of one brand of tobacco or another, as well as their safety. The pictures above show different examples of cigarette advertisements published in newspapers and magazines in the United States in the mid-twentieth century.

«IT IS NO SURPRISE THAT THE TOBACCO

INDUSTRY USED HEALTH CLAIMS IN

THE ADVERTISING OF CIGARETTES DURING

THE 1950s AND 1960s" 


\section{Whos $m$ Inlerul! sintitis bialdibial (2) \\ NTION \\ findings» (Thun, 2005). The emphasis has been added, although the reader probably does not need it, because his words perfectly show the important role of the media, even according to these intrepid researchers. \\ THE TOBACCO INDUSTRY ALREADY KNEW \\ It is no surprise that the tobacco industry used health claims in the advertising of cigarettes during the 1950s and 1960s (Figure 1). Their advertising used people who were considered to be exemplary, like health care professionals, to publicise the merits of one brand of tobacco or another, as well as their safety. The media survive mainly thanks to advertising revenue, so they shamelessly (and probably with very little information) welcomed such advertising. In 1954, in response to other research on the direct carcinogenic effect of tobacco, tobacco companies launched the campaign (today it would be considered an advertorial) A frank statement to cigarette smokers (Figure 2) in the most important magazines and newspapers in the United States. The «frank statement» publication attributed statements like «there is no proof that cigarette smoking is one of the causes» of lung cancer to scientific experts. It marks the beginning of the tobacco industry's strategy of spreading misinformation among the citizens regarding the effects of tobacco on health.}

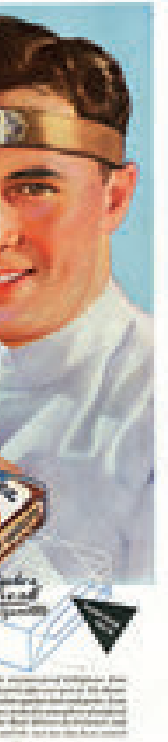

\section{A Frank Statement to Cigarette Smokers}

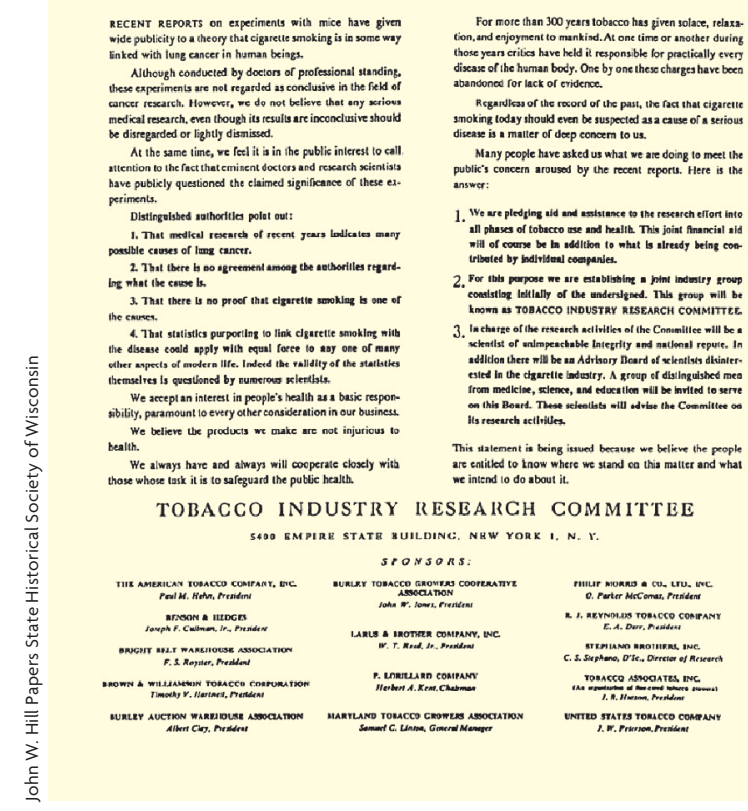

Figure 2. In response to research connecting tobacco and lung cancer, tobacco companies launched the campaign $A$ frank statement to cigarette smokers in magazines and newspapers in 1954. It was the beginning of the tobacco industry's strategy to spread misinformation among the citizens regarding the effects of tobacco on health.

\section{THE TOBACCO INDUSTRY TRIED TO INFLUENCE THE MEDIA}

The tobacco industry pressured the media because they understood that media coverage influences the population's behaviour. A study by SotoMas, Villalbí, Granero, Jacobson and Balcazar (2003) analysed internal industry documents (released after tobacco companies' trial in the United States and publication of the Master Settlement Agreement ${ }^{1}$ in 1998) and revealed the industry's strategies for attracting journalists. For instance, in November 1984 a conference for Latin American journalists was organised in Madrid to «have the tobacco industry's point of view clearly and fairly

\footnotetext{
${ }^{1}$ An agreement reached in the United States in 1998 between, on the one hand, the lawyers of 46 states, five territories and the District of Columbia, and on the other, the main tobacco companies regarding the advertising and marketing of their products.
}

stated by exposing leading journalists to myths and realities about passive smoking (Figure 3), the economic impact of the tobacco industry, the negative effects of restrictive advertising, etc.» (Rothermel, 1984) or by organising the travel arrangements for journalists specialised in health issues (from La Vanguardia and $E l$ Mundo) to the United States to be shown the marvels of Philip Morris's activities (Winokur, 1995).

The different ways the industry tried to influence journalists, informants and the media has been investigated, including the aforementioned documents or actively in the case of new laws (smoke-free spaces, prohibition of smoking in cars, etc.). Among their most frequent activities, travel to special events are organised, usually in privileged locations, combined with extraprofessional activities, as well as press releases as a source of information for journalists (Hiilamo, Kahl, \& Lambe, 2009), although the effect 


\title{
WHILIP MORRIS INTERNATIONALE C ENEER DOFFICE CORRESPONDENICE T2O PARK AVENUE, NEW YORK, N.Y. 10017 \\ ID: Mr. Andrew Whist \\ UtC 5 1984 \\ DATE:December 3, 1984 \\ FROM: Tim Rothermel Ti/Co/kue \\ R. W. MURRAY
}

SUBECT: Conference of Latin American Journalists in Madrid

\begin{abstract}
On 27 and 28 November, I participated in the first two days of a three day PMI conference: in Madrid for twelve journalists from Spain and Latin America. As you know, the purpose of this conference was to have the tobacco industry's point of view clearly and fafirly gtated by exposing leading journalists to myths and realjtiles about passive smoking, the economic impact of the tobacco industry, the negatlve effects of restrictive advertising, etc. Although only. time will tell whether these objectives are fully met, in my view, the effort will be highly successful,
\end{abstract}

Figure 3. Another strategy used by the tobacco industry was to organise meetings to present their point of view on passive smoking, its economic impact and the effects of restrictive advertising legislation to journalists and pundits. The picture shows a Philip Morris document about a conference in Madrid in 1984 for Spanish and Latin American journalists, which was organised to that end.

on the media and journalists seems rather weak, with the exception of economy magazines.

A United States study (Pierce \& Gilpin, 2001) on mass media news about health and tobacco between 1950 and 1983 proved the association between media coverage and changes in the rates of smoking cessation. Because of this, the World Health Organization (WHO) and the tobacco control movement included denouncement of the tobacco industry's manoeuvring to manipulate the media among their priorities (World Health Organization, 2000).
In Spain, the existence of the discussion in the media for most of 2005, before the Law 28/2005 for health care measures against smoking was passed (the law was passed on 26 December 2005 and entered into force on 1 January 2006), is evidence of the media's importance. As described in the 2006 Informe Quiral (Fundació Vila Casas, 2007), the covers of the most important national newspapers included information on the proposals, negotiation of and amendments to the new law, with an approximate average of forty news items about tobacco per month, and a peak in

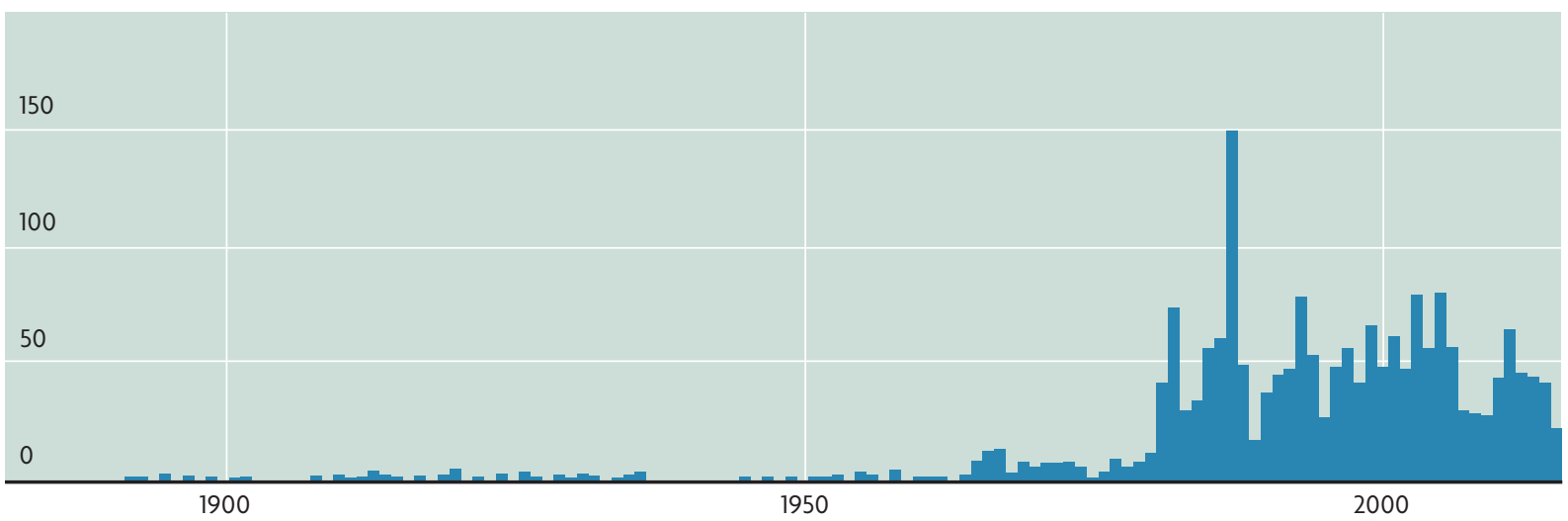

Figure 4. The graph shows the number of articles published in La Vanguardia including the word «tabaquismo" (tobacco use) over time (1881-2015). 

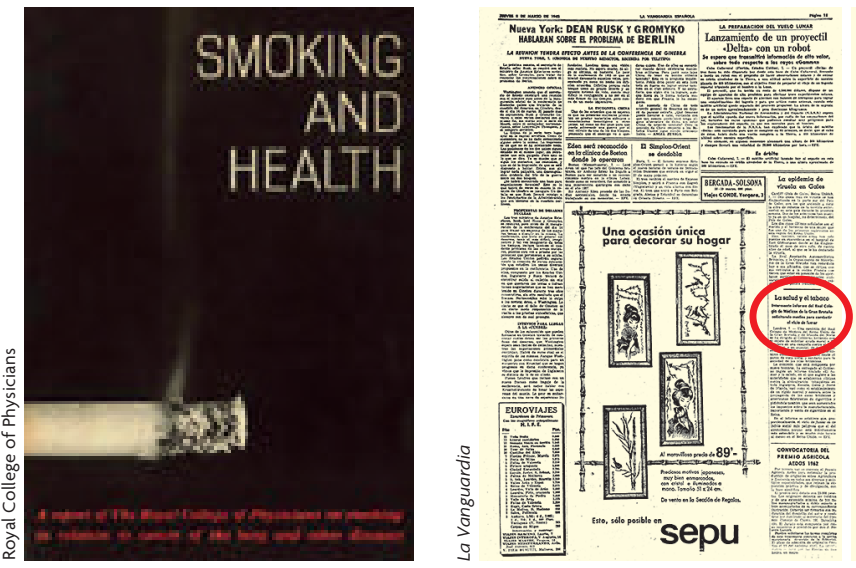

\section{La salud y el tabaco}

Interesante informe del Real Colegio de Médicos de la Gran Bretaña solicitando medios para combatir el vicio de fumar

Londres, 7. - Una comisión del Real Colegio de Médicos del Reino Unido de la Gran Bretaña y de Irlanda del Norte se ha dirigido al Gobierno británico con el objeto de solicitar ayuda moral y financiera en una campaña contra el vicio de fumar, y en especial, de fumar cigarrillos, que el Colegio de Médicos británicos considera un grave daño desde ol

Figure 5. On the left, the 1962 "Smoking and Health» report from the Royal College of Physicians of the United Kingdom. On the right, a brief note in La Vanguardia days after the report was published.

December 2005 of over 200. The 700 news items about tobacco in 2005 almost doubled the figure published between 2002 and 2004, and tripled those of preceding years (1997 to 2001). This trend can also be observed in the news published by the veteran Spanish newspaper La Vanguardia, which has accessible online information about issues as far back as 1881, as shown in Figure 4.

The treatment of tobacco news has changed gradually over time. For instance, La Vanguardia was very timid in the way it presented the «Smoking and Health» report from the Royal College of Physicians of the United Kingdom, issued on 6 March 1962 in London. The report was only mentioned in a brief agency news note two days later (Figure 5).

Evidently, the media have directed advertising and information on tobacco since it became established as a huge business, and the industry has tried to influence the media and its informants. Despite this, in Spain and in other developed countries, the media have been decisive in creating the social change required to control tobacco use. $\odot$

\section{REFERENCES}

Atusingwize, E., Lewis, S., \& Langley, T. (2015). Economic evaluations of tobacco control mass media campaigns: A systematic review. Tobacco Control, 24(4), 320-327. doi:10.1136/tobaccocontrol-2014-051579 Doll, R., \& Hill, A. B. (1950). Smoking and carcinoma of the lung; preliminary report. British Medical Journal, 2(4682), 739-748. Hiilamo, H., Kahl, U., \& Lambe, M. (2009). The Philip Morris Nordic journalist program: Strategies, implementation and outcomes. Health Policy, 89(1), 84-96. doi:10.1016/j.healthpol.2008.05.003
Fundació Vila Casas. (2007). Informe Quiral 2006. Barcelona: Fundació Vila Casas.

Levin, M. L., Goldstein, H., \& Gerhardt, P. R. (1950). Cancer and tobacco smoking; a preliminary report. Journal of the American Medical Association, 143(4), 336-338.

Pierce, J. P., \& Gilpin, E. A. (2001). News media coverage of smoking and health is associated with changes in population rates of smoking cessation but not initiation. Tobacco Control, 10(2), 145-153. doi:10.1136/ tc.10.2.145

Rothermel, T. (1984). Conference of Latin American journalists in Madrid. (Núm. Id. 2023272337-2338). Retrieved from https:// industrydocuments.library.ucsf.edu/tobacco/ docs/\#id=qkpm0114

Royal College of Physicians. (1962). Smoking and health. London: Royal College of Physicians. Retrieved from https://www. rcplondon.ac.uk/projects/outputs/smokingand-health-1962

Soto-Mas, F., Villalbí, J. R., Granero, L., Jacobson, H., \& Balcazar, H. (2003). The tobacco industry's internal documents and smoking prevention in Spain. Gaceta Sanitaria, 17(3), 9-14

Surgeon General's Advisory Committee on Smoking and Health. (1964). Smoking and health. Washington: Office of the Surgeon General.

Thun, M. J. (2005). When truth is unwelcome: The first reports on smoking and lung cancer. Bulletin of the World Health Organization, 83(04), 144-145. doi 10.1590/S0042-96862005000200015

Winokur, M. N. (1995). Spanish media trip. August 8, 1995. (Num. Id. 2050765956). Retrieved from https://industrydocuments.library.ucsf.edu/ tobacco/docs/\#id=spcj0124

World Health Organization. (2000). Tobacco industry strategies to undermine tobacco control activities at the World Health Organization. Retrieved from http://www.who.int/tobacco/resources/publications/ general/who_inquiry/en/

Wynder, E. L., \& Graham, E. A. (1950). Tobacco smoking as a possible etiologic factor in bronchiogenic carcinoma; a study of 684 proved cases. Journal of the American Medical Association, 143(4), 329-336.

Esteve Fernández. Director of the Tobacco Control Unit at the Catalan Institute of Oncology (ICO), in L'Hospitalet de Llobregat (Barcelona, Spain), a centre which collaborates with the WHO on Tobacco Control. He is also Professor in the Department of Clinical Sciences at the University of Barcelona. 